\title{
Co-Creation of University Project Teams as a Trend in the Digital Economy
}

\author{
Chernysheva T.L.
}

\author{
Novosibirsk State Technical University, Novosibirsk, Russia \\ Email: tablack@mail.ru
}

\begin{abstract}
The article reveals the trends in the digital economy that have a direct impact on the educational process of universities. These include, first of all, the emphasis on knowledge, the compatibility of creativity, the network nature of interaction, and interdisciplinarity. The necessity of mobilizing the efforts of the faculty aimed at motivating research students to freshmen by involving them in solving urgent problems for the city and the region, many of which lie in the plane of digitalization of production and service processes, is proved. It is concluded that the university project team, which includes teachers and students of different areas of training, united by the principle of interest in the object of study, is most consistent with the current global strategy for the generation and transfer of technology.
\end{abstract}

Keywords: digital economy, synergy, co-creation, university project team, digital ecosystem, innovation,

smart city

\section{REFLECTION OF DIGITAL ECONOMY TRENDS IN THE EDUCATIONAL AND UPBRINGING PROCESS INSIDE THE UNIVERSITY}

The digital economy focuses on knowledge, which is why it is also called the knowledge economy: knowledge becomes an integral part of goods and services, modern industries turn into a kind of educational institution [1]. However, this process cannot be one-sided: educational institutions, in turn, become a kind of intellectual value added industry. On the territory of universities today, meetings of manufacturers and consumers of high-tech products can take place: ideas prompted by consumers are analyzed by the scientific community, converted into technology, and then become part of new goods and services. The digital economy requires high-quality marketing research and the creative abilities of developers, and all this is concentrated in universities.

Another trend in the digital economy is the joint activity within the framework of project teams, which crystallize on the basis of enthusiasm for the topics of a particular project from specialists in various fields. All of them have extended powers when there is no need to climb the hierarchical administrative ladder to ensure the adoption of key decisions. As a result, the product is not created sequentially, but in parallel, a horizontal organization provides equal access to the entire range of information to all interested parties: customers, suppliers, and end users. A transition is being made to horizontal organization, an active exchange of information flows takes place both within the team itself and with the outside world.

\begin{abstract}
Wherever project team members are located, communication takes place through space and time. However, in our opinion, the most suitable place for these teams is a university, which has the most important and demanded resource in the digital economy: human capital. Team members have the ability to establish communications, conduct bidirectional communications, adapting to rapidly changing external circumstances. They prefer to share useful information and their own research, and such an integrated world economy based on mutual interests and cooperation has received the name "economy of trust" [2].

Decision making is based on data coming from a huge number of people and devices, and the result depends on how much the responsible person trusts this data. The problem of reliability today is transferred to information and relations between the client and the manufacturer of goods or services, therefore, trust at the present time is the cornerstone of economic relations in their traditional and virtual form [3].

Co-creation is the most important trend in the digital economy, which is embodied in the creation of startups for university project teams. Within teams, the responsibilities between the participants are clearly distributed, each has its own functions, information freely circulates between all members of micro-teams. You can't go on without trust in teamwork.

Collaboration and creativity, the synergy of efforts naturally lead to the network nature of the interaction of all participants, so the third most important alter ego of the
\end{abstract}


digital economy is the economy of network and interconnection based on the integration of human intelligence into a network [1]. Consciousness becomes inherent not only in the individual and the project team but also in the organization, the whole holding, the state. Such a corporation of educators and trainees as a university has such a consciousness. Being a kind of intellectual network itself, organized from the ideas of the individuals that make it up, the university also has an online platform focused on providing various educational services to external audiences, a platform for communication. By teaching, the university thus permanently learns itself. The generation of innovations is carried out both offline and online, goes into interactive mode.

A unique network system of participants connected by common interests, that is, a digital ecosystem is being created at the university. And the greater the activity of such interconnected systems is, the more effective is the development of a digital economy, which can also be called an ecosystem economy [4].

The combined efforts give more than the sum of the components, so the university's top management needs to develop measures to encourage cooperation and cocreation of professors, students and graduate students, to facilitate the creation of project teams. It is these efforts that can affect how quickly the flowering of network production, network business, network healthcare, and network training will take place in our country.

The university should occupy a central place in several regional clusters. Indeed, the model of network collaboration teams involves involving a wide variety of groups of society in the process of generating innovations that form a certain innovation ecosystem, including large production companies and government bodies.

\section{HORIZONTAL PRINCIPLE OF ORGANIZATION OF UNIVERSITY PROJECT TEAMS}

So, the digital economy is in dire need of human capital, which can only be created through an innovatively organized educational process in higher education. The center of scientific and technical creativity of students in collaboration with the university technopark could unite student research teams working on various projects, supervised by experts from the university and from enterprises in the region. Scientific work should be carried out in stable teams not from the contest to the contest or the competition for a grant, but on an ongoing basis.

Even in the first year, an expert commission should identify those students who are distinguished by critical and non-standard thinking, logic, and the desire to create something new. Usually such young people are easily involved in project work, and under the influence of a personal example of a mentor who is passionate about scientific activities, they begin to produce new ideas. At the stage of their public presentation, one should select those proposals that are of practical importance, and with the help of all the members of the expert council functioning at the center of scientific work of students, try to bring these developments to the level of products that can be promoted in the real economy. Each talented student should be assigned a member of the expert council, that is, an assistant professor or professor of the corresponding faculty, who would personally oversee the activities of his ward for a specific project, give all new tasks and recommendations for its implementation, and also monitor the dynamics of his growth as a beginning scientist. All this work can be done during official consultation hours or during extracurricular hours. Thus, as a result of well-coordinated work of at least ten tightly interacting communities of "teacher-student", "teachertwo-three students" communities within their microcollectives, one can already get the initial database of innovative projects within a year. Every year this base will increase, the number of research teams will increase. Students from different scientific teams should be introduced to each other, brought them together in the framework of a seminar common to all at the same university site, and here they should be taught the basics of innovative management, entrepreneurial activity, and taught the basics of promotion through business games. So inter-faculty contacts will be made as the basis for interdisciplinary projects. University project teams match the characteristics of the "turquoise companies" that F. Lalu wrote about. in his work "Discovering the Organizations of the Future" [5]. In the "turquoise" companies there is trust in the principle of selforganization, the principle of management without command and control. The challenge for management is to support teams' desire for decentralization and selforganization. It is important that everyone can equally feel that they are influential and responsible for making decisions in that complex collaboration of organisms, which is the organization. This should also be the principle of training at universities that generate start-ups: horizontal decentralized learning, which without pressure can unlock the unique potential of young people, releasing their innate abilities.

The interdisciplinary orientation of the activities of university teams should be strengthened by a network resource on which each team will post materials related to its project, and the results of the work of diverse teams should be open to each other with the aim of "interpollinating" knowledge and ideas. It is advisable to place this resource on the basis of the MOODLE electronic educational environment, which is just used to create dynamic websites for students in various fields, regardless of the level of source and received education. This virtual learning environment [6] has a sufficient set of module components for courses: chat, survey, forum, blog, glossary, workbook, lesson, lecture, seminar, test, questionnaire. MOODLE has effective tools for creating tests [7].

All these resources must be tuned according to the strategic goal - the development of breakthrough ideas. 
Almost every university has a subordinate school where students study, to which university representatives should pay attention. Children who successfully participate in various school, city, regional and regional contests can also be "joined" to university teachers, preferably to graduate students who would be engaged in career guidance work with them, to identify scientific interests, and form a tendency and flair for new developments. So, even before entering a university, actually applicants may have scientific topics that will remain with them for all their student years, and, probably, for the rest of their lives. Many interesting forms of work can be demanded inside such small research teams, consisting of 1-5 young people and a mentor. An indispensable condition for the effectiveness of their functioning is a personalized approach to everyone and a high level of trust. It has been established that it is precisely the levels of trust and identity that make a complex contribution to the objectactivity and socio-psychological effectiveness of the group perceived by the eyes of the group [8]. This suggests that, first of all, the mentor should be inspired by scientific work and believe in its success, and for this he should treat his wards as partners, consult with them on important issues of the development of the scientific direction, create traditions of the team, perhaps, think through its original name and even a visual image. Thus, self-esteem motivation will be formed among young people, which acts as a predictor of academic and scientific sustainability, making a positive contribution to academic achievement [9].

It's great if the university has an exhibition space. Schoolers can be attracted by an interesting exposition, where they would receive a visual presentation of the development of students and university teachers. It could be like a museum in which, on the material of exhibits presented by all faculties, again, humanities students prepared by teachers could conduct excursions on an ongoing basis, telling about physical, chemical, biological patterns and how they are displayed in technology proposed by university scientists.

\section{UNIVERSITY PROJECT TEAMS IN THE FIGHT FOR THE "SMART REGION"}

However, the success of this initiative will be largely determined by how exciting the problems they solve will be for young people. And here the role of the faculty and professors of the university is huge because, in order to determine the topic of scientific research for each talented student, it is necessary to have a number of modern scientific "reserves" standing on the first flank and waiting for their developer. The problems that the educational units based on the center - student - professor, school student - graduate student will deal with will be of interest only if they are relevant, the need of society should be felt in them. Therefore, these micro-collectives should be open to the city, regional community, and, therefore, to solve those problems that can really improve the life of the city, in this way the university can become a driver for the development of its territory.

The most important thing that needs to be broadcast to students and future students, that is, applicants, is the desire and ability to occupy their niche in the urban socioeconomic landscape and realize their capabilities with the efficiency that is embedded in them. For this, the university should become a research center for the problems of the city and the region, an executor of orders for the development of the solutions they need in various industries. The closest relationship should exist between the city and the university, leading both to improving the functioning of the city itself and to improving the most important areas of the modern university, its three missions: education, science, communication with society. And it is the third mission that contributes to the appearance of changes in the first two. If the university has contacts with the city and regional community, new orders will appear from city-forming enterprises for research, which, in turn, will affect the quality of the educational process: students will learn a lot and will be motivated to make their own contribution to the development of their territory.

When creating a center for studying regional problems in the department of scientific and technical work of students, one should rely on its growth points. If we talk, for example, about Novosibirsk, then we can't but rely on its flagship projects such as the development of industrial production of carbon nanotubes and nanomodifiers; production of modern biotechnological preparations and enzymes for feed production; creation of innovative micro-, nano-, bioelectronics; full cycle of deep processing of aluminum; development of materials for high-tech medicine; creation of an industrial automation system; production of powder and metallurgical products, development of 3D printers on the platform of the cluster of additive digital technologies and industries, production of laser spraying systems; the generation of new biopharmaceuticals and antibiotics, as well as developments for the industrial Internet and the Internet of things in the framework of the megaproject "Smart Region" [10].

The latest project is relevant for all regions, however, in each territory the developments will differ in local features, which will need to be taken into account by the innovative scientific teams of universities. The spread of smart cities is inevitable, and investment in infrastructure over the next 20 years will amount to $30-40$ billion dollars. Ordinary cities, step by step, turn to the use of innovative technologies in all aspects of the life of citizens. This is the response to critical damage and threats, the fight against traffic jams, the creation of comfortable living conditions for citizens, the automation of the urban economy and so on. The introduction of "smart technologies" can improve the life of a metropolis, due to an increase in the quality of life of each of its residents.

The maturity of the "smart city" of the 21 st century will be manifested not only in the use of information technologies, but primarily in the transfer of emphasis from the 
processes of production or construction of objects of the material environment to the processes of efficient operation of the continuous life cycle of objects. The challenges of our time could be called increased urbanization, increased mobility of the population, the rapid development of communication technologies. In this regard, the risks of anthropogenic, natural and sociopsychological nature increase [11].

The modern city consists of many subsystems: transport, telecommunications, public utilities, water, gas, heat, electricity, as well as many others that function and interact with each other. How, for example, informational interaction of all these technical systems and authorities for ensuring response and prevention of threats to public safety is guaranteed? Obviously, there are new challenges to public safety and the rule of law that must be addressed. In this regard, the task for scientific student teams may be the development of new technologies that must be implemented for a comfortable life in the city [12].

Each city has its own unique transport system, which is distinguished, first of all, by its management system. It is important to find out the source and causes of transport collapses that any city cannot avoid anyway, so you should look at what decision-making technologies and systems for monitoring the development of transport in this particular city exist, and how transport development programs are linked with urban development programs. Future technologies lead to a city without traffic lights, to unmanned vehicles, to car sharing as the main means of transportation around the city. All these are modern directions for research [13].

It is obvious that the city is gradually turning into an intellectual ecosystem, this is a tendency of the future that has already come. Digital transformation helps the city be seen as a computer program in a data processor. This program accumulates all the main directions of the city's functioning, such as healthcare, education, energy, transport, water, culture. Therefore, the development of various computer programs that increase the efficiency of a particular life process is of particular relevance. The important question here is that the era of big data can dramatically change life in the city and you should think about how to prepare its residents for this, so that they can take advantage of the opportunities and not be surprised when they use public and private structures, for example, unlimited access to data storage systems, methods of conducting a census based on big data, a machine audit procedure, and collecting taxes on the blockchain [14].

Every day, the infrastructure of urban solutions for population mobility is being improved, payment is being developed and improved, ways of moving in the city, communication, and the range of entertainment is expanding. In this regard, it is important to determine how to use the infrastructure of mobile devices being implemented everywhere for work and life. After all, it is she who can make the life of a city dweller richer and more interesting.

Digital stops, smart stores, and media will appear that will turn the city into a media space. The city space will integrate as a media with new technologies for creating and socializing content. Therefore, the issue of creating new technologies for the formation, placement, and distribution of content in the public space seems very relevant for consideration. It is obvious that the era of the Internet of things will completely change the life of a city dweller [15].

In many large cities, high-tech medicine is already developing today. Future technologies are known: these are robots-pharmacists, transplantation of organs printed on a $3 \mathrm{D}$ printer, sensors-controllers of the state of internal organs connected to the network. To the approximation of these technologies to the practice of life, specific areas of scientific research are involved, and students should be interested in them [16].

It is important for young people starting to work on development to know which enterprises in their place of residence are city-forming, which of them are undergoing modernization and, therefore, what needs they may have on the way to technological progress. The youth of the city have a unique chance, communicating on an ongoing basis with the enterprise, to participate in equipping specific industries with intelligent technologies, in offering products that will be in demand on the world and domestic markets. At the enterprises, in turn, there should be people who can advise universities what specific areas of scientific research will contribute to import substitution, which industries need intellectual support with new developments.

Cities are market leaders in global competition for investment. The task of the city is to offer the best conditions, the best infrastructure for the development of business and people's lives. Students may be given the task of figuring out which sectors of urban public infrastructure are most in need of investment, and which mechanisms to attract investment can be developed.

The study of the city and the entire region from the point of view of tourist infrastructure, their suitability for receiving guests is another important area of research. The current situation in the inner tourism market creates unique opportunities for Russian cities to realize their tourism potential. The federal marketing projects "Travel Russia" and "Visit Russia / Time to relax in Russia" $[17,18]$ are focused on promoting the country as an attractive tourist destination, stimulating the demand of Russian and foreign tourists for traveling around Russia. At this point are important answers to questions about what technological and marketing solutions are required for each specific city to create a competitive tourist product, what types of tourism and products will be in demand among travelers in the near future, how efficiently TIC (tourist information centers) operate in terms of promotion key centers of urban leisure. The technologies for the formation of a tourist and recreational cluster, which will include a city with its attractions, this is what can captivate students of humanities and economic departments.

Obviously, all these practical tasks for the sustainable development of the territory can be solved on the basis of the university - and in the field of transport, improving 
http://imbe.vvsu.ru/fin/pubs/article/details/material/140 20/ispolzovanie_elektronnoy_obrazovatelnoy_sredy, Retrieved 03/15/2019

[7] O.I. Vaganova, Z.M. Smirnova, M.V. Mukhina, M.M. Kutepov, L.I. Kutepova, T.L. Chernysheva, "The Organization of the Test Control of Students' Knowledge in a Virtual Learning Environment MOODLE", Journal of Entrepreneurship Education, 2017, Vol:20, Issue 3, p.4

[8] A.V. Sidorenkov, I.I. Sidorenkova, N.YU. Ul'yanova, "Doverie i identichnost' kak faktory effektivnosti proizvodstvennyh grupp", Psihologicheskij zhurnal, Moskva: Izdatel'stvo "Nauka", 2016, T.37, No. 2, S.29-42.

[9] T.O. Gordeeva, V.V. Gizhickij, O.A Sychyov, T.K. Gavrichenkova, "Motivaciya samouvazheniya i uvazheniya drugimi kak faktory akademicheskih dostizhenij i nastojchivosti v uchebnoj deyatel'nosti", Psihologicheskij zhurnal, Moskva: Izdatel'stvo "Nauka", 2016, T.37, No. 2, S.57-68.

[10] V.V. Kuleshov, G.A. Untura, V.D. Markova, "Razvitie ekonomiki znanij: rol' innovacionnyh proektov v programme reindustrializacii regiona", Region: ekonomika i sociologiya, Novosibirsk: Izdatel'stvo SO RAN, 2016, T.3. (91), S. 28-54.

[11] A. SHalaginov "Kak sdelat' gorod umnee. Reshenie Smart city", Connect. Mir svyazi, Moskva, 2012, No.11 (199), P. 34-35.

[12] M.A. SHneps-SHneppe "Kak stroit' umnyj gorod", CHast' 1 Proekt "Smart cities and communities" v programme ES Horison 2020 [How to build a smart city. Part 1. The project "Smart Cities and Communities" in the EU Horison 2020, Mezhdunarodnyj zhurnal otkrytyh informacionnyh tekhnologij (International Journal of Open Informational Technologies), 2016, Vyp. No. 1 (4), P.12-19.

[13] V.A. Cvetkova, E.V. Mel'nikova, O.A. Mel'nikov, "Puti modernizacii nacional'nogo informacionnogo mekhanizma dlya obespecheniya innovacionnogo razvitiya obshchestva", Rossiya: tendencii i perspektivy razvitiya, Moskva: INION RAN, 2012, Vyp.7, ch. 1, S. 432-441.

[14] 03.12.2016 VEF: Innovacionnye tekhnologii 20202030-h godov URL: http://innopraktika.ru/upload/Digest_08.12.pdf,

Retrieved 15.12.2019
[6] A.V. Koren' "Ispol'zovanie elektronnoj obrazovatel'noj sredy MOODLE v sozdanii interaktivnyh uchebnyh kursov novogo pokoleniya. Territoriya novyh vozmozhnostej", Vestnik Vladivostokskogo gosudarstvennogo universiteta ekonomiki i servisa, Vladivostok: Izd-vo VGUES, 2013, T. 1, URL: 
[15] L. Molchanovskij, O. Mel'nikov, "Koncepciya "intellektual'nogo zdaniya" i perspektivy ee razvitiya", Connect. Mir svyazi, Moskva, 2012, No. 3, S. 68-71.

[16] Vysokie tekhnologii, fundamental'nye i prikladnye issledovaniya $\mathrm{v}$ fiziologii i medicine: sbornik trudov Pervoj mezhdunarodnoj nauchno-prakticheskoj konferencii "Vysokie tekhnologii, fundamental'nye i prikladnye issledovaniya $\mathrm{v}$ fiziologii i medicine", 2326.11.2010, Sankt-Peterburg, Rossiya, Sankt-Peterburg: Izd-vo Politekhnicheskogo un-ta, 2010, T. 4, 402 s.

[17] Puteshestvuj po Rossii, URL: http://strana.ru/, Retrieved 14.12.2019.

[18] Visit Russia. Vremya otdyhat' v Rossii, URL: http://www.visitrussia.com/, Retrieved 12.12.2019

[19] G. Badhavan, "Dumaj kak inzhener. Kak prevrashchat' problemy v vozmozhnosti", Moskva: Mann, Ivanov i Ferber, 2016, S. 92. 